\title{
Cross-Cultural Competence of Communicators as a Way to Create a Positive Eco- Informational Environment
}

Klara M. Abisheva, ${ }^{+*}$ Karakat M. Nagimzhanova, ${ }^{*}$ Ryskeldy A. Aykenova, ${ }^{\dagger}$ Aizhan K. Kapanova, ${ }^{\dagger}$ Zina Sh. Koldasbayeve, ${ }^{\hat{\imath}}$ and Aisulu D. Kanapyanova

\section{Abstract}

This research is dedicated to the study of the essence of the phenomenon of cross-cultural competence, the acquisition of cross-cultural competence, which seems necessary in the context of globalisation. The aim of the article is a clarification of the definition of cross-cultural competence and description of its structure, types of knowledge (subject and procedural) in it, methods and strategies for its assimilation. A number of research methods were deployed to accomplish the objectives of the research - observation, survey, cognitive analysis, modelling, text information analysis method, linguo-ecological analysis, interview and sociolinguistic survey method. The research obtained the following scientific results: the definition of cross-cultural competence is given, its signs are revealed, types of knowledge are indicated in it, methods and strategies for mastering it as well as its frame model are presented. The novelty of the work lies in the development of the theoretical foundations of cross-cultural competence and studying the strategies and tactics for mastering it. The article deals with the problems of a new branch of knowledge - ecolinguistics, one of the areas of which is translation and focus of attention on the negative aspects of intercultural communication. Theoretical significance to practical value is the main provisions and conclusions of the article can be used in the development of the theory of crosscultural communication applied in the practice of cross-cultural teaching.

Keywords: Competency-Based Approach, Ecolinguistic Approach, Cognitive Analysis, Concept, Environmental Thinking

\footnotetext{
${ }^{+}$Department of Social Humanities and Language Disciplines, Turan Astana University, 010013, Astana, Republic of Kazakhstan

${ }^{*}$ Corresponding Author, Email: abishevakm@mail.ru

${ }^{\ddagger}$ Department of Pedagogy and Psychology, Turan Astana University, 010013, Astana, Republic of Kazakhstan

î Department of Foreign Languages, Russian Language and Literature; Arkalyk State Pedagogical Institute named after Y. Altynsarin, 110300, Arkalyk, Republic of Kazakhstan

' Department of History of Kazakhstan and the Humanities, Kazakh National University of the Arts, 010000, Astana, Republic of Kazakhstan

(C) 2019 Abisheva et al. This is an Open Access article distributed under the terms of the Creative Commons Attribution License (http://creativecommons.org/licenses/by/2.0), which permits unrestricted use, distribution, and reproduction in any medium, provided the original work is properly cited.
} 


\section{Introduction}

The interpretation of many linguistic phenomena and problems of intercultural communication in modern linguistics is due to a radical ecological turn of this science. At the present stage, a new branch of knowledge is being formed - ecolinguistics, which studies both the factors which have a negative impact on the development of a language and factors related to finding the ways to enrich the language and improving the culture of speech and communication of ecolinguistics speakers. This branch of knowledge that is being studied is the state of the language as a semiotic system (its semiotic health).

Scientists in this area have shown an in-depth interest in describing the forms of language integration, peaceful coexistence, language tolerance, focusing on the development of the principles of "intercultural communication", "dialogue of cultures" by means of a language. The formation of the intercultural (social) competence of speakers of different national languages is recognised in this case as the most crucial task of linguodidactics and methods of teaching foreign languages (lonova, 2006: 9091). Mastering cross-cultural competence is understood as a part of communicative competence which aim is to develop language and speech abilities (Malkova, 2000) and consider it a "multilingual and multicultural competence" (Galskov \& Gez, 1998: 43).

Currently, the need for mastering intercultural competence is immeasurably increasing. In the era of globalisation, there is an increasing trend towards crowding out national cultural expressions and the coexistence of global and local cultures; the need for a common language in the process of intercultural communication is increasing, the role of oral speech (oralisation, dialogisation, pluralisation and personalisation of communication) is increasing (Sternin, 2010: 13). According to A.O. Laletina, in the modern world, there is an increase in the proportion of conflict communication (Laletina et al., 2011: 42).
All this contributes an unfavourable environment for communication, which in turn contributes to the implementation of conflict situations of communication, - "the negative speech environment of the existence of communicants" (Vernadsky, 2004: insert page number). The information environment can be considered as a synonym for the noosphere. (Vernadsky, 2004), and the "semiosphere" (Yu.M. Lotman, 2000). According to Yu.M. Lotman, the "semiosphere" forms the communicative-semantic structure of the noosphere - the biosphere organised by rational human thought - considered as a system of symbolic support of consciousness (Lotman, 2000). The intercultural information environment can be considered as the biosphere (noosphere) in which both the psychosphere is combined - the environment where the psychological, intellectual and spiritual life takes place (Zvegintsev, 1996: 159-160) and the sign sphere - the semiosphere because the psychosphere is expressed in language as a repository of public consciousness (Zvegintsev, 1996: 163; Evstratova et al., 2016; Akhmetshin et al., 2018). The research aims to identify the essence of this type of competence and describe its structure. The results of the research can find application in intercultural communication, in linguodidactics and the practice of teaching in foreign languages.

To achieve this aim, the research carried the following tasks:

- Studied the works that consider the intercultural competence of communicators;

- Determined the degree of communicative knowledge about the values of one's own, and the other people's society and the degree of knowledge, skills and types of perception;

- Determined the types of competencies, that are formed as a result of the implementation of any abilities;

- Studied the particularities of creative abilities; 
- Studied the particularities of the language picture of the world of other nations.

The research, though, begins with a brief review of the literature.

\section{Literature Review}

A review of the literature on the problem of competence shows that different research examines various types of competence and gives them inadequate definitions (cite these references). In the works of E.G. Elizarova (2005), communicative competence is understood as a foreign language competence which possesses a set of such characteristics as:

- Dynamism, which is demonstrated in the fact that the ideas (knowledge) of communicants are constantly changing;

- Implicitness (competence is characterised as implicit knowledge);

- Complexity (complex nature of a foreign language) competence is demonstrated in the fact that it includes components of a psychological, anthropological and sociological nature and is not only a linguistic phenomenon;

- Relativity (none of the foreigners cannot possess complete communicative competence in the studied language) (Elizarova, 2005: 221-223).

Under the intercultural competence, B.K. Bazylova and G.A. Kazhigalieva understand the competence aimed not only at mastering knowledge about national cultures and languages but also at removing the "friend-foe" contradiction (Bazylova \& Kazhigalieva, 2015: 46). Intercultural competence is considered as a synonym for "ethnocultural competence and is defined as a body of knowledge, ideas about other cultures that are realised through skills and attitudes that ensure effective interaction with representatives of these cultures" (Lebedeva, 2008: 116).

T. Stefanenko believes that ethnocultural competence in the process of intercultural communication contributes not only to the demonstration of a positive attitude towards the presence of various ethnocultural groups in society, characterised as "the ability to understand their representatives and interact with partners from other cultures" (Stefanenko, 2008: 103). According to K.V. Khabarova, N.A. Timofeyeva and N.A. Malysheva, when teaching foreign students Russian as a foreign language, attention should be focused on the formation of the ethnocultural competence of students, which is not only a set of ideas about the specificity of a frequent culture, but also the ability to apply this knowledge in the practice of interaction with representatives of this culture, taking into account their particularities" (Khabarova et al., 2017: 149-150). R.Henvi (1994) seemingly argues that there are four levels of cross-cultural competence in the course of which the communicator focuses on the differences of cultures and their inadequacy (I-II level) and only at the III level comes to an understanding that "justified and rational in the eyes of the carrier of another culture, and only at the fourth level, the communicant learns to perceive "alien culture" through the eyes of its carrier (Henvi, 1994).

Cross-cultural competence is formed when a communicator masters such types of perception as empathy and transcendence. In case of empathy, the communicator learns to see himself in the place of another person and transsection is understood as the next step of mental development when a person learns to think and feel like another person does, associates himself with him, perceives his beliefs. Cross-cultural competence is understood as the ability and willingness of an individual to communicate from another culture (Wiseman, 2003; Vinichenko et al., 2017). The methodological issues are discussed in the next section.

\section{Methodology}

The study uses a complex methodological paradigm which includes a variety of approaches, principles and methods, namely, competence as well as psycho-cognitive and linguo-ecological approaches. In other words, this research combines the methods of various sciences that are necessary for studying a complex object. Principles applied in the article 
are consciousness, active learning, linguoecological and cognitive principles. Working methods are characterised as interactive. Competency-based approach contributes to the formation of eco-cross-cultural competencies as a body of knowledge necessary for communication and understanding of the others in a favourable sphere. The linguo-cultural approach contributes to the development of the values and norms of another culture on the basis of studying the linguoculture as units, containing in its structure information about the values, sociocultural attitudes and mentality of other people and learning about the language picture of the world of other people as a set of concepts (Ionova, 2006; Apakhayev et al., 2017).

The cognitive principle involves the integration of knowledge from various sciences for the study of a complex object. The linguoecological principle is aimed at studying the object as an ecosystem that includes various components aimed at creating an information system favourable for communicators. The modelling method is used in the process of building a frame of "eco-cultural competence, models of various situations of intercultural communication, modelling the behaviour of communicants in situations of "defective" and sufficient competence, in situations of modelling the desired modifications of personal behaviour (Onyusheva et al., 2018: 149). Moreover, in these cases, a modelling method is the primary means of changing behaviour (Bandura, 2007). The method of frame semantics is associated with the process of conceptualising the concept of eco-cultural competence and its types. It allows to simulate the principles of structuring and reflecting an inevitable part of human experience, knowledge in the meanings of language units as well as the ways to enhance general knowledge (Boldyrev, 2004: 29). The method of included observation is used in collecting factual material on the behaviour of communicants in the process of intercultural communication. The method of the psycholinguistic associative experiment is used to identify the associations of respondents which arise on the stimulus-presented word, idiom, concept and linguistic culture of another language. When processing the results of the experiment, attention is focused on the level of competence of the respondent, his possession of various types of competence. The following sections discuss the results of the research.

In the process of conducting a free-associative experiment (Table 1), we involved 80 respondents from different nationalities. They were shown 40 stimulus words (linguoculture) realities and idioms. The task of the experiment was to study the content of images of the linguistic consciousness of representatives of different cultures, to establish differences in the content of images of consciousness. The experiment aimed to find out the answers to the words-stimuli, the determination of the level of competence and the nature of the perception of another communicant.

\section{Results}

The concept of eco-cross-cultural competence is a new term of an emerging science - eco-crosscultural science, the conceptual apparatus of which, as well as its ontological, epistemological and methodological foundations are under development. Psycholinguistic associative experiment, the methodology of which is described by R.M. Frumkin suggests the study and analysis of respondents' answers to the word-stimulus. The response is an associative reaction that follows immediately (Frumkin, 2003). 


\begin{tabular}{|c|c|c|c|c|}
\hline $\begin{array}{l}\text { Word to } \\
\text { stimulate - } \\
\text { shanyraq } \\
\text { (the ceiling } \\
\text { in yurts) } \\
\end{array}$ & $\begin{array}{l}\text { Topical } \\
\text { meaning }\end{array}$ & Paradigmatic & Syntagmatic & Mentallysymbolic \\
\hline Russian & $\begin{array}{l}\text { The ceiling } \\
\text { of the } \\
\text { house, } \\
\text { circle, vault }\end{array}$ & $\begin{array}{l}\text { The ceiling of the } \\
\text { house }\end{array}$ & black, ceiling & \\
\hline Kazakh & $\begin{array}{l}\text { Vault of the } \\
\text { yurt, house }\end{array}$ & $\begin{array}{l}\text { Large house, } \\
\text { parents' house, } \\
\text { otau (house), } \\
\text { newlyweds' } \\
\text { house, shanyrak } \\
\text { is associated with } \\
\text { the house, where } \\
\text { rules the } \\
\text { harmony }\end{array}$ & $\begin{array}{l}\text { Kara Shanyraq- } \\
\text { Parents' House of } \\
\text { Otau, Shanyrak } \\
\text { ynbiikBolsyn (may } \\
\text { your house be } \\
\text { strong) Shanyrak } \\
\text { ortagatuspesin (may } \\
\text { the family not } \\
\text { collapse) }\end{array}$ & $\begin{array}{l}\text { Shanyraq is associated } \\
\text { with the sky, with one } \\
\text { of the parts of the } \\
\text { cosmological model of } \\
\text { the world among the } \\
\text { Kazakhs according to } \\
\text { which it stands out. }\end{array}$ \\
\hline Kazakh: qaz & $\begin{array}{l}\text { Bird, neck, } \\
\text { clouds }\end{array}$ & $\begin{array}{l}\text { Modest long- } \\
\text { necked, bird }\end{array}$ & $\begin{array}{l}\text { Qaz baur (porous } \\
\text { clouds), not changed, } \\
\text { gooseneck, stand up }\end{array}$ & $\begin{array}{l}\text { Upper world (where } \\
\text { live the Gods of } \\
\text { Tengri) middle world } \\
\text { where people live, the } \\
\text { lower world - the } \\
\text { place of dead people. } \\
\text { Home of Kazakh } \\
\text { (numnah house) is } \\
\text { associated with this } \\
\text { world: shanyrak } \\
\text { means the head of the } \\
\text { sun, uik (fastening the } \\
\text { skeleton of the yurt - } \\
\text { the body), this kerege } \\
\text { means the walls of the } \\
\text { house, the yurt } \\
\text { symbolically } \\
\text { represents the model } \\
\text { of the cosmos }\end{array}$ \\
\hline Russian & bird & $\begin{array}{l}\text { rogue, } \\
\text { important, } \\
\text { irritation }\end{array}$ & $\begin{array}{l}\text { Goose frowning, } \\
\text { important goose, } \\
\text { such a goose, decent } \\
\text { goose, like water off } \\
\text { a goose, good goose }\end{array}$ & $\begin{array}{l}\text { Associated with } \\
\text { negative connotations, } \\
\text { value orientations: } \\
\text { positive (bird) and } \\
\text { negative when } \\
\text { characterising a } \\
\text { person, symbolic value }\end{array}$ \\
\hline $\begin{array}{l}\text { English } \\
\text { people }\end{array}$ & Bird & & & \\
\hline
\end{tabular}




\begin{tabular}{|c|c|c|c|c|}
\hline $\begin{array}{l}\text { Word for } \\
\text { stimulus }\end{array}$ & Thematic & Paradigmatic & Syntagmatic & Mentallysymbolic \\
\hline $\begin{array}{l}\text { Kazakh: } \\
\text { maslenitsa } \\
\text { (a type of } \\
\text { holiday) } \\
\end{array}$ & holiday & & & \\
\hline $\begin{array}{l}\text { Russian: } \\
\text { maslenitsa }\end{array}$ & $\begin{array}{l}\text { Farewell the } \\
\text { winter, } \\
\text { pancakes, quiet } \\
\text { evenings, } \\
\text { playful } \\
\text { gourmet, } \\
\text { Saturday with } \\
\text { parents }\end{array}$ & $\begin{array}{l}\text { Holiday } \\
\text { mummers, } \\
\text { farewell, } \\
\text { remembrance, } \\
\text { fire }\end{array}$ & All carnival & $\begin{array}{l}\text { Meeting the sun of spring. } \\
\text { Pancakes - the cult of the } \\
\text { deceased. The first pancake } \\
\text { was not eaten, placed on } \\
\text { the dormer window or } \\
\text { given to the poor, to the } \\
\text { remembrance of the soul }\end{array}$ \\
\hline $\begin{array}{l}\text { Russian: } \\
\text { old file }\end{array}$ & & Scoundrel & & $\begin{array}{l}\text { Negative Value } \\
\text { Orientations }\end{array}$ \\
\hline Kazak & $\begin{array}{l}\text { A special kind } \\
\text { of white bread }\end{array}$ & & & \\
\hline
\end{tabular}

Table 3. Words-Reactions of the Kazakhs, the Russians and the English to the Linguistic Culture of English Culture

\begin{tabular}{|c|c|c|c|c|}
\hline $\begin{array}{c}\text { The word } \\
\text { for stimulus }\end{array}$ & Thematical & Paradigmatic & Syntagmatic & Mentallysymbolic \\
\hline $\begin{array}{l}\text { Russians: } \\
\text { time }\end{array}$ & $\begin{array}{l}\text { Day: } \\
\text { morning, } \\
\text { evening, } \\
\text { night, } \\
\text { present, } \\
\text { past }\end{array}$ & $\begin{array}{l}\text { Season, spring, } \\
\text { winter, } \\
\text { summer, day } \\
\text { and night, } \\
\text { calendar, time, } \\
\text { oldness, youth }\end{array}$ & $\begin{array}{l}\text { Time to scatter and } \\
\text { collect stones, an hour } \\
\text { has struck, when the } \\
\text { hell freezes over (when } \\
\text { cancer on the } \\
\text { mountain whistles), till } \\
\text { doomsday, till the cows } \\
\text { come home (after } \\
\text { Friday, on Thursday), }\end{array}$ & \\
\hline Kazaks: time & $\begin{array}{l}\text { Day, night, } \\
\text { tomorrow, } \\
\text { hour, now, } \\
\text { past, July, } \\
\text { midday, } \\
\text { twilight, } \\
\text { evening }\end{array}$ & Time, June & Time is gold & $\begin{array}{l}\text { Situational: milking } \\
\text { time of mare } \\
\text { (biesauimuakyt- } 1,5 \\
\text { hours), cooking the } \\
\text { food time (et pisirim } \\
\text { uakyt-2 hours), the } \\
\text { necessary time for } \\
\text { boiling water for tea } \\
\text { (shay kaynatuuakyt - } \\
40-60 \text { min ) }\end{array}$ \\
\hline $\begin{array}{l}\text { English } \\
\text { people }\end{array}$ & $\begin{array}{l}\text { Time, } \\
\text { present, } \\
\text { morning, }\end{array}$ & $\begin{array}{l}\text { Calendar, } \\
\text { pasttime }\end{array}$ & $\begin{array}{l}\text { Shooting season, time } \\
\text { forbids, }\end{array}$ & $\begin{array}{l}\text { Time is money, time } \\
\text { presses, connect time }\end{array}$ \\
\hline
\end{tabular}




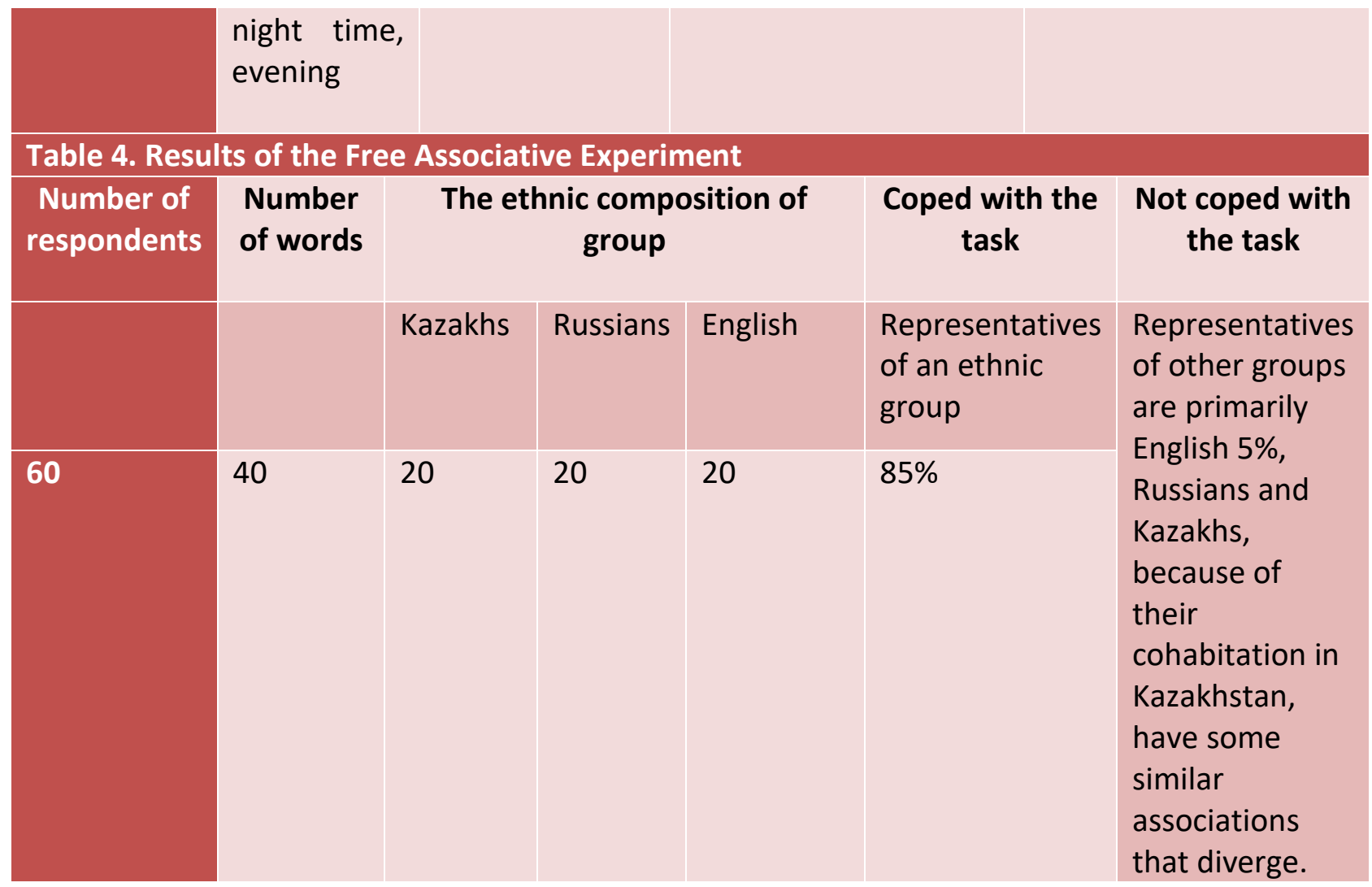

\begin{tabular}{|c|c|c|c|c|c|c|}
\hline & \multicolumn{2}{|c|}{ Own perception } & \multicolumn{4}{|c|}{ Type of perception } \\
\hline & $\begin{array}{l}\text { empathy } \\
\text { rejection } \\
\text { perception } \\
+\end{array}$ & sympathy & alienation & foreigner & ethnic prejudice & $\begin{array}{l}\text { Rejected } \\
\text { perception }\end{array}$ \\
\hline Kazakhs & & $\begin{array}{l}\text { If a } \\
\text { neighbour } \\
\text { lives in the } \\
\text { same } \\
\text { territory, } \\
\text { countryman }\end{array}$ & & $\begin{array}{l}\text { Heterostereotype } \\
\text { hospitable }\end{array}$ & $\begin{array}{l}\text { Asian, five } \\
\text { fingers } \\
\text { (besbarbachniki- } \\
\text { used to eat with } \\
\text { the help of five } \\
\text { fingers), Kalbit, } \\
\text { cross-eyed, } \\
\text { horde }\end{array}$ & + \\
\hline Germans & & & + & $\begin{array}{l}\text { Heterostereotype: } \\
\text { punctual honour } \\
\text { "Ordnung" } \\
\text { workers }\end{array}$ & $\begin{array}{l}\text { Thelma Fritz } \\
\text { sausage box }\end{array}$ & + \\
\hline English & & & + & $\begin{array}{l}\text { Heterostereotype: } \\
\text { restrained, } \\
\text { reasonable value } \\
\text { time and money }\end{array}$ & $\begin{array}{l}\text { John Bull, } \\
\text { puddings, } \\
\text { children of } \\
\text { Albion }\end{array}$ & + \\
\hline
\end{tabular}




\begin{tabular}{|l|l|l|l|l|}
\hline Americans & + & $\begin{array}{l}\text { Heterostereotype: } \\
\text { business, } \\
\text { calculating, } \\
\text { friendly, energetic, } \\
\text { patriotic }\end{array}$ & $\begin{array}{l}\text { Uncle Sam, } \\
\text { smiley, } \\
\text { adventurers }\end{array}$ \\
\hline French & + & $\begin{array}{l}\text { Heterostereotype: } \\
\text { frivolously }\end{array}$ & Frog-eater & + \\
\hline Japanese & + & $\begin{array}{l}\text { Heterostereotype: } \\
\text { polite }\end{array}$ & Yellow-belly \\
\hline Italians & & $\begin{array}{l}\text { Heterostereotype: } \\
\text { noisy }\end{array}$ & $\begin{array}{l}\text { Wop (pasta- } \\
\text { eaters) }\end{array}$ & + \\
\hline Caucasians & & $\begin{array}{l}\text { Caucasians hetero- } \\
\text { stereotype } \\
\text { cruel }\end{array}$ & $\begin{array}{l}\text { Black, black-ass, } \\
\text { (persons of } \\
\text { Caucasian } \\
\text { nationality) }\end{array}$ \\
\hline
\end{tabular}

We used in our work a free-associative

experiment that is one of the devices that allows experiment aimed at studying the consciousness looking indirectly at the characteristics of the of multilingual communicants, carriers of a kind formation and functioning of the human of national culture since it is a free-associative linguistic consciousness (Goroshko, 2001: 5).

\begin{tabular}{|c|c|c|c|}
\hline $\begin{array}{l}\text { Number of } \\
\text { respondents }\end{array}$ & $\begin{array}{l}\text { Stimulus words: } \\
\text { ethnonyms }\end{array}$ & $\begin{array}{l}\text { Rejection of } \\
\text { perception }\end{array}$ & "Own" perception \\
\hline $80 \%$ & $\begin{array}{l}\text { Kazakhs, } \\
\text { Germans, } \\
\text { French, British, } \\
\text { Americans, } \\
\text { Italians, } \\
\text { Japanese, } \\
\text { Caucasians }\end{array}$ & $78 \%$ & $\begin{array}{l}\text { 22\%. Causes: increased intercultural } \\
\text { contacts, market development, } \\
\text { cultural and language expansion, } \\
\text { neighbourhood, fraternity, mobility, } \\
\text { partial socialisation in another culture }\end{array}$ \\
\hline
\end{tabular}

Table 7. Psycho-linguistic experiment. The degree of communicative knowledge about the values of their own and someone else's society and the degree of knowledge, skills and types of its perception

Representatives

of linguo-

Degree of variation in

Degree of mastering the knowledge of skills of types of perception

cultural

communities

\section{Russians,}

Kazakh knowledge of values

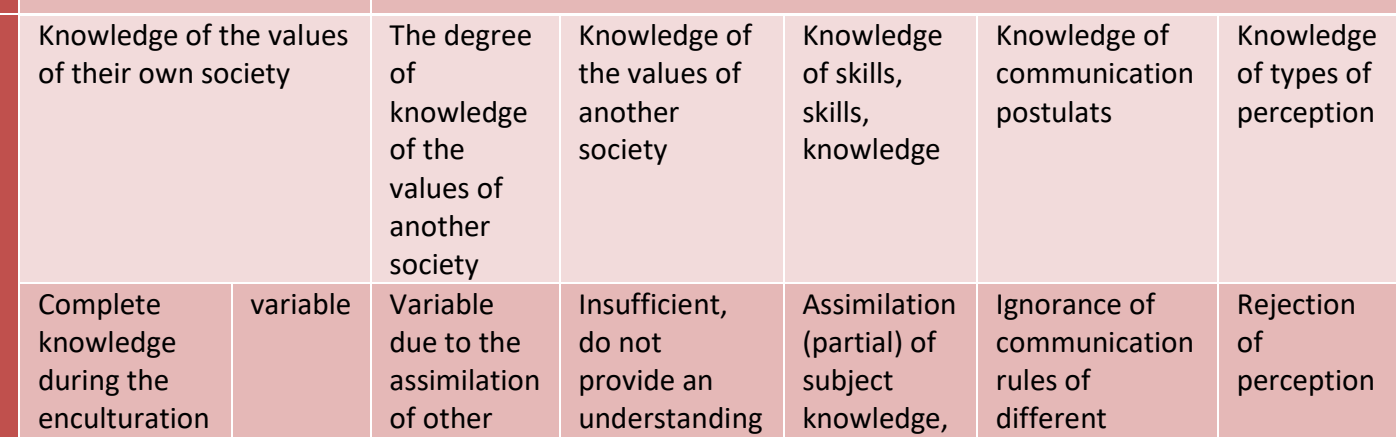




\begin{tabular}{|c|c|c|c|c|c|c|c|}
\hline & & & $\begin{array}{l}\text { cultural } \\
\text { patterns }\end{array}$ & & $\begin{array}{l}\text { non- } \\
\text { mastering } \\
\text { skills usage } \\
\text { of } \\
\text { knowledge }\end{array}$ & $\begin{array}{l}\text { nations (an } \\
\text { agreement, } \\
\text { cooperation, } \\
\text { dialogue) }\end{array}$ & \\
\hline$\%$ & $95 \%$ & $85 \%$ & $30 \%$ & $70 \%$ & $35 \%$ & $40 \%$ & $80 \%$ \\
\hline
\end{tabular}

Culture as a set of values should be assimilated by the society members in the process of socialisation. However, at the same time, cultural values can be both general and variable, so according to F. Sharafian (Sharifian, 2011: 515), the consciousnesses of the members of society constitutes a cultural network.

The results of a psycholinguistic experiment to determine respondents' knowledge of representatives of linguocultural communities of their own and other cultural values show that community members have full $(95 \%)$ or partial (85\%) understanding of the cultural artefacts of their social system. The analysis of knowledge and skills necessary in the process of intercultural communication shows that they are not sufficiently learned: knowledge of skills and abilities of the subject is $35 \%$, knowledge of communication postulates is $40 \%$, the manifestation of alienated perception in the process of communication and foreigners is $80 \%$.

\section{Discussion}

A review of the literature shows that in most cases, scientists consider the indiscriminate types of linguistic communicative linguocultural, intercultural, foreign language and cross-cultural competence, but there is still no precise definition of the term intercultural communication, descriptions of its structure, definitions of the types of its descriptors (Silagadze, 2017; Silagadze, 2018). R.S. Jeger understands competence as a basic ability (not inherited either genetically or biologically), but acquired by an individual and formed internally in the process of self-motivated interaction with the world (Jeger, 2010).

The types of competencies that are formed as a result of the implementation of any abilities are:

- social competence is the ability to share information, communicate, establish and maintain social ties;
- personal competence is the attitude to the world work and oneself, discipline motivation, self-awareness and flexibility;

- methodological competence is the ability to develop, select and apply appropriate strategies for solving problems, possession of critical thinking and ability to learn;

- business competencies are knowledge and skills that go beyond a specific culture of the sphere (Sheper, 2010: 297).

In our opinion, eco-cross-cultural competence is vital for communicators of intercultural communication. Its structure can be complicated and have many components: grammatical, discursive sociolinguistic (Canale \& Swain, 1980), organisational (covering the formal aspects of communication) and pragmatic (focusing attention) on the functional aspect of communication (Bahman \& Palmen, 1986). According to A. Knapp-Potthoff and K. Knappintercultural, communication includes three components: affective, cognitive and strategic (Knapp-Potthoff \& Knapp, 1982). Crosscultural competence characterised as communicative competence includes:

- knowledge (necessary information for effective interaction),

- motivation (a positive attitude towards another culture),

- skills (necessary behavioural skills for effective interaction) (Griffin, 2006: 64).

The work of Griffin Emori correctly identifies the components of cross-cultural competence (knowledge, skills and motivation) necessary for the communicator. However, all these specified components of intercultural communication do not sufficiently clearly contribute to the replenishment of intercultural knowledge, nor they are sufficient for the understanding of the 
representation in the situation of communication.

In the structure of eco-cross-cultural competence, we consider the creative abilities described as intercultural aimed at the formation of this type of competence. Such creative abilities include cognitive-psychological and pragmatic cognitive-psychological abilities which are understood more widely than language ability defined by Yu.N. Karaulov as a non-layered set of linguistic abilities and readiness to carry out speech acts of varying degrees (Karaulov, 2007). If speech ability is aimed at learning the language and using it in various situations, then the cognitivepsychological ability involves the development of the psychological functions of the individual in the human psychosphere. V.D. Shadrikov believes that abilities are the properties of functional systems that implement individual mental functions which have an individual measure of severity and are demonstrated in the success and qualitative uniqueness of the development and implementation of activities (Shadrikov, 2012: 142).

Natural abilities can be completed by a system of intellectual operations that develop essential mental functions: perception, memory, imagination, representation, and thinking (Shadrikov, 2012: 143). The main mental functions include language and knowledge since knowledge is a product of the receptive speech and cognitive activity of a person, and a language is a form of expression of thought, representation and imagination of a person, the results of his perception in the memory of a person.

Knowledge is formed in the process of scientific and naive cognition of the world around, drawing up a concept, understanding its subjects, conceptualising this concept by comparing the concept of an object with the others, highlighting its distinctive features. The essence of knowledge consists of a reliable generalisation of the facts in which there are the necessary, the regular and the individual in common for the random (Spirkin, 2001). A person extracts them during the actualisation of three factors: nature (external conditions of people's life), culture, considered as an antonym of the notion "nature", so "culture is something that a person did not receive from the natural world but brought, did or created [herself]/himself" (Manakin, 2004: 51) as cognitive knowledge as cognitive activity.

By distinguishing concepts of the linguistic picture of the world of other nations, the linguistic culture of other culture, the communicator supplements its operations with analogies (establishing similarities, similarities with other concepts and linguistic cultures) and associations (establishing connections between new words in the process of conducting a contrast analysis). We propose to distinguish the structure of this complex phenomenon, various subtypes of competences developing in the process of realisation of the communicative, psychological ability of the communicant, namely:

Linguocultural competence can be understood as "knowledge of the whole system of cultural values expressed in language as the ideal speaker" (Vorobyev, 2006: 44). We believe that linguoculturological competence should be viewed as a bicultural set of values and skills of representing knowledge and skills of using them in the process of communication. "The cultural scenario is understood as an abstract mental structure which is based on the speaker's interpretation of a situation of extra-linguistic reality as a repeating dynamic process consisting of a set of episodes and having a set of participants with fixed fields" (Plotnikova, 2005: 32). According to A. Wezhbitskaya, "differences between cultures lie in quality" (Wezhbitskaya, 2001: 164). In the native culture, a person knows that every sign has "two sets of information: a reflexive layer, knowledge and methods of actions" (Ufimtseva, 1995: 57). However, when borrowing values (artefacts of culture, words of another language, and linguistic culture ), usually "only the reflexive layer (knowledge) is borrowed, but the method of action with the subject, as a rule, cannot be borrowed" (Ufimtseva, 1995: 60). 
Cognitive and psychological competence is a combination of knowledge and skills to implement "one's own" and "someone else's" perceptions, categorisation and attribution of the world within the other culture. To do this, a person should not feel prejudice against someone else, but, on the contrary, show empathy towards him or her, understood as a transition from his/her own vision of the world to the recognition that there are the equal experience and attitude of another individual (Byram \& Morgan, 1986).

- Sociolinguistic competence is a combination of knowledge and skills of the differentiated use of one's own and foreign languages depending on the situation of communication and stratification variables (social status of the speaker, his social positions, social roles, social relations).

- Pragmatic competence is a set of knowledge and technology about speech and communication in the situation of intercultural communication, the postulates and strategies of communication, cooperation, politeness, tolerance, etc.

- Ecolinguistic competence is understood as a set of knowledge and technology to ensure a safe tolerant information environment of communicants, which is aimed at ensuring mutual understanding. To apply these laws, the technology of linguo-ecological analysis is used.

The composition of species competencies in the composition of eco-cross-cultural competence was determined on the basis of psycholinguistic associative experiments (Tables 1-3), which were obtained during the conducted research aimed at studying the competencies of communicants, studying the types of their perceptions and identifying the degree of variation in knowledge of the values of their own and other society, degree of knowledge, skills and types of perception. The results of the experiments are reflected in Tables 4, 5, 6 and 7. As a result of the experiments, it was established the need for a broad understanding of eco-crosscultural competence as a body of knowledge, technology as the ability to communicate with the others in the process of intercultural communication, in the structure of which different sub-competencies are distinguished: linguo-cultural rhetoric that assimilates the language and cultural scenarios of its application and skills of perception of "someone else", a manifestation of empathy and sympathy for him and desire to understand his feelings and experiences.

Ecolinguistic competence is aimed at mastering knowledge and skills of maintaining a safe information environment of communication. Ecocross-cultural competence is formed as a result of updating the cognitive and psychological abilities of the communicant. The results obtained in the course of the research will find application in the practice of intercultural communication as well as contribute to the theory of cross-cultural competence.

\section{Conclusion}

The central purpose of the research was to probe the cross-cultural competence of communicators as a way to create a positive ecoinformational environment. In the result of the studying competence as a body of knowledge necessary for the study of another language and the implementation of intercultural competence, scientists have studied various types of competence, given their definitions. However, such types of competence (communicative, linguistic, ethnocultural and cross-cultural) could not be used to enrich the information potential of communicants and improve their skills since:

- focused on any side of the competence (mastering the cultural knowledge of other people, enhancing the literacy of people, the study of the type of perception of the communicant, empathy), contributing to his adaptation to someone else's;

- subject knowledge was studied in isolation from the technology of its application;

- competences were considered out of touch with personal abilities; 
- knowledge and skills contributing to the safety of the environment of the communicant environment were not considered.

Meanwhile, the results of psycholinguistic experiments showed that a communicator of intercultural communication required versatile knowledge and skills. They allow not only mastering topics or other knowledge, but also mastering technology that contributes to the accumulation of sociocultural experience of communicants in "alien" cultural environment when exploring the cultural scenarios of cultural artifacts of other people, the skills of using knowledge, norms, and postulates of communication. In accordance with other cultural models, we need skills aimed at maintaining contact with the "alien", its correct perception (empathy and sympathy) and understanding in the course of interaction.

\section{References}

Akhmetshin, E.M., Sharafutdinov, R.I., Gerasimov, V.O., Dmitrieva, I.S., Puryaev, A.S., Ivanov, E.A., \& Miheeva, N.M. (2018). Research of human capital and its potential management on the example of regions of the Russian Federation. Journal of Entrepreneurship Education, 21(2), 1528-2651-21-2-172.

Apakhayev, N., Koishybaiuly, K., Khudaiberdina, G., Urisbayeva, A., Khamzina, Z.A., \& Buribayev, Y.A. (2017). Legal basis for ensuring freedom of access to information on the operation of state administration bodies in Kazakhstan. Journal of Advanced Research in Law and Economics, 8(3), 722-729.

Bahman, L.F., \& Palmen, A.S. (1986). The Construct Validation. Cross-Cultural Orientation. New York: University Press of America.

Bandura, A. (2007). Learning Through Modelling. Theories of Personality. Saint Petersburg: Peter.

Bazylova, B.K., \& Kazhigaliyeva, G.A. (2015). The Role of the Ethno-Linguistic Didactic Approach in the Formation of Intercultural Competence of Multilingual Specialists. International Journal of Applied and Basic Research, 12-6, 46-50.
Boldyrev, N.N. (2004). Conceptual Space of Cognitive Linguistics. Questions of Cognitive Linguistics, 1, 18-36.

Byram, M., \& Morgan, C. (1986). Thing and culture. Clevedon: Press of America.

Canale, M., \& Swain, M. (1980). Theoretical Bases of Communicative Learning. Applied Linguistics, 1(1), 1-47.

Elizarova, G.V. (2005). Culture and Communication to Foreign Languages. Saint Petersburg: Karo.

Evstratova, T., Shalashnikova, V., Starostenkov, N., Nakhratova, E., Zotova, A., \& Ziroyan, M. (2016). Practical aspects of volunteer movement development in Moscow. Research Journal of Pharmaceutical, Biological and Chemical Sciences, 7(3), 2073-2081.

Frumkin, R.M. (2003). Psycholinguistics. Moscow: Academy Publishing Center.

Galskov, N.D., \& Gez, N.N. (1998). Theory of Teaching Foreign Languages. Moscow: Akademiya Publishing Center.

Goroshko, E.I. (2001). Integrative Model of a Free Associative Experiment. Kharkiv, Moscow: RA-Caravella Publishing Group.

Griffin, E.A. (2006). First Look at Communication Theory (6 Ed). New York: McCrawhill.

Henvi, R. (1994). Achievable global perspective. Ryazan: TISBI, 1994.

Ionova, S.V. (2006). Approximation of the content of secondary texts. Volgograd: VolSU Publishing House.

Jeger, R.S. (2010). Bologna Process: Learning Outcomes and Competence Approach. Astana: Independent Kazakhstan Agency for Quality Assurance in Education (IQAA).

Karaulov, Yu.N. (2007). Russian and Linguistic Personality. Moscow: Publishing House LKI.

Khabarova, K.V., Timofeyeva, N.A., \& Malysheva, N.A. (2017). Features of the Formation of Ethnocultural Competence of Foreign Students in the Process of Teaching Them the Russian language. Innovative Science International Scientific Journal, 4-2, 148-151. 
Knapp-Potthoff, A., \& Knapp, K.F. (1982). Fremdsprachenlernen und - lehren. Stuttgart: Kohlhammer W.

Laletina, A.O., Gritsenko, E.S., \& Sergeeva, M.V. (2011). Gender in British and American Linguistic Culture. Moscow: Flinta, Nauka.

Lebedeva, N. (2008). Ethnic and cross-cultural psychology. Moscow: MAKS Press.

Lotman, Yu.M. (2000). Semiosphere. Saint Petersburg: Arts St. Petersburg.

Malkova, E. (2000). Formation of Intercultural Competence in the Process of Working on texts for Reading. Moscow: Moscow State Linguistic University.

Manakin, V.N. (2004). Comparative Lexicology. Kyiv: Znaniya.

Onyusheva, I., Ushakov, D., \& Van, H.T. (2018). The eco-problems and green economy development in Kazakhstan: An analytical survey. International Journal of Energy Economics and Policy, 8(2), 148-153.

Plotnikova, S.N. (2005). Language, Communication and Discursive Personality: to the Problem of Differentiation of Concepts. In Linguistic Discourse (pp. 5-16). Irkutsk: Irkutsk State Linguistic University.

Shadrikov, V.D. (2012). Psychology of abilities: anthology. Moscow: Moscow Psychological and Social Institute.

Sharifian, F. (2011). Cultural Conceptualisations and Language: Theoretical Framework and Applications. Amsterdam/Philadelphia: John Benjamins.

Sheper, H. (2010). Competence of University Graduates, Professional Requirements and Conclusions for the Reform of Higher Education. In Bologna process, Learning Outcomes and Competence Approach. Book-Appendix 1 (pp. 120-129). Astana: Research Center for Higher
Education Quality Problems, Independent Kazakhstan Agency for Quality Assurance in Education (IQAA).

Silagadze, A. (2017). "Post-Soviet paradoxes" of unemployment rate. Bulletin of the Georgian National Academy of Sciences, 11(1), 136-141.

Silagadze, A. (2018). Some aspects of economic ideas in Shota Rustaveli's "the knight in the panther skin". Bulletin of the Georgian National Academy of Sciences, 12(1), 161-167.

Spirkin, A.G. (2001). Philosophy. Moscow: Gardariki.

Stefanenko, T.G. (2008). Ethnopsychology: Practicum. Moscow: Aspect Press.

Sternin, I.A. (2000). Social Factors and the Development of Modern Russian Language. Theoretical and Applied Linguistics. Language and Social Environment, 2, 4-16.

Ufimtseva, N.V. (1995). Ethnic and Cultural Stereotypes: Cross-Cultural Research. Izvestia RAN. Series of Literature and Language, 54(3), 55-62.

Vernadsky, V.I. (2004). Biosphere and noosphere. Moscow: IRIS-PRESS.

Vinichenko, M.V., Karácsony, P., Demcheko, T.S., Ilina, I.Y., \& Makuchkin, S.A. (2017). Improvement of youth personnel policy: Social inspection. Eurasian Journal of Analytical Chemistry, 12(7), 1069-1077.

Vorobyev, V.V. (2006). Linguoculturology. Moscow: RUDN Publishing House.

Wezhbitskaya, A. (2001). Understanding Cultures through Key Words. Moscow: Languages of Slavic Culture.

Wiseman, R. (Ed.). (2003). Intercultural Communication Theory. London: Sage Publications.

Zvegintsev, V.A. (1996). Thoughts on linguistics. Moscow: Moscow University Press. 